\title{
The Euro
}

\section{a Political Failure and an Economic Disaster \\ Jespersen, Jesper}

Published in:

International Journal of Political Economy

DOI:

10.1080/08911916.2016.1159082

\section{Publication date:}

2016

\section{Document Version}

Peer reviewed version

Citation for published version (APA):

Jespersen, J. (2016). The Euro: a Political Failure and an Economic Disaster. International Journal of Political Economy, 45(1), 33-39. https://doi.org/10.1080/08911916.2016.1159082

\section{General rights}

Copyright and moral rights for the publications made accessible in the public portal are retained by the authors and/or other copyright owners and it is a condition of accessing publications that users recognise and abide by the legal requirements associated with these rights.

- Users may download and print one copy of any publication from the public portal for the purpose of private study or research.

- You may not further distribute the material or use it for any profit-making activity or commercial gain.

- You may freely distribute the URL identifying the publication in the public portal.

\section{Take down policy}

If you believe that this document breaches copyright please contact rucforsk@kb.dk providing details, and we will remove access to the work immediately and investigate your claim. 


\title{
The 'Euro': a political failure and an economic disaster
}

\author{
Jesper Jespersen*
}

\begin{abstract}
Professor Parguez is right when he claims that the 'euro' is a political failure and an economic disaster, in which French politicians and economists seem to have played a significant role. France's elite envisaged being a dominant political power on the Continent after the two military defeats of Germany in 1918 and 1945. The two strategies the elite tried were very different, but they both failed. A heavy war indemnity in 1919 and the common European currency in 1990 were seen by the French elite as instruments to suppress Germany's potential economic (and political) superiority.
\end{abstract}

The French economic elite, represented by F. Perroux and Jacques Rueff, supported academically the elite's aspiration of being the leading power within a uniting Europe by academic arguments. The academic support to the Mitterrand government's EU-policy was organized by the former Minister for Finance (and later president of the European Commission), Jacques Delors. He headed the Committee on the Study of Economic and Monetary Union, which unanimously recommended a common European currency 'to the benefit of European prosperity'.

According to Parguez, the resulting common currency created at a French initiative is the prime reason for the present European economic defeat, which has frustrated the French aspiration of playing a leading role being primus inter pares on the Continent. This is so because the rules we are bound to follow make no economic for Europe as a whole, which is collectively denied by the European elites.

This short commentary discusses whether the economic profession not only in France, but in general, is incompetent, ideologically biased or simply a 'rent seeking' profession.

Keywords: The crisis of the European Union, Euro, France's mistakes, false economic arguments 
* Dr. scient. adm., Ph.D. (econ.) Jesper Jespersen is Professor of Economics at Roskilde University. A member of the EMU committee appointed by the Council for European policy, he submitted a minority opinion concerning the Danish membership of the EMU before the Danish referendum in 2000. He has in particular undertaken research into Danish exchange rate policy in relation to the EMU and has contributed at several Parliamentary hearings on EMU respectively in January 2009 and February 2012. He is particularly grateful to Bruno Amoroso, Claude Gnos and Victoria Chick for many valuable suggestions, without any commitments.

\section{Intellectual delusion}

Professor Parguez addresses a very relevant and timely question: 'Why was there no political debate about the soundness of the [European common currency] system?' (p.2). The paper starts out in the inter-war period. At that time the gold standard was the canonical international monetary system. Hardly any economist challenged the gold standard as an overruling and theoretically sound system; it was only the gold content of the national currency which was disputed in the 1920s. As we know, Britain did choose the old, i.e. pre-war, gold parity, which immediately created a balance of payments problem. France took another path by reducing the gold parity considerably, which gave a short lived boost to French competitiveness. But during the Great Depression in the 1930s France hung on, much too long to the gold standard, making the unemployment problem and the depression deeper than in many comparable countries.

Hence, monetary theory came into disarray. But a new macroeconomic understanding had to wait until the publication of Keynes's ' The General Theory of Employment, Interest and Money' in 1936. Furthermore, it took time to digest this new theory. However, Keynes’s macroeconomic theory was a theoretical sea-change, so since then no serious macroeconomist can claim that the gold standard and the quantitative theory of money (and prices) was the only theory in town!

Keynes demonstrated theoretically that 'money' is not neutral, in two senses: 1 . in pure macroeconomic theory explaining reality and 2. in practice when macroeconomic policies are undertaken governments need money. Although a member of the Liberal Party, Keynes developed his new macroeconomic understanding in an attempt to understand why unemployment persisted 
and production was stagnating even though the fundamental assumptions behind the (neo)classical economic policies were fulfilled: wage flexibility and a balanced public budget.

Keynes's claim was that the national macroeconomic system cannot adjust by itself to facilitate full employment. The private sector cannot through the market system be expected to establish via increased flexibility and competition a balance (equilibrium) between financial saving and real (physical) investment at full employment - information, institutions and, therefore, policy are lacking. Due to uncertainty, there is even a risk that 'free' market forces and flexible wage adjustment would aggravate the imbalances.

Keynes's original analysis focussed on the national level: how to stabilize macroeconomic development and by active policies bring it closer to full employment, which he considered an essential liberal goal. Later he expanded his analysis and brought the international aspect into consideration. But one should not forget that in 1933 Keynes wrote 'National Self-Sufficiency', where he raised the questions, what can a rich country obtain in economic terms by free trade, free capital movements, etc? At that time, he did not even mention giving up nation's own currency. He did not hesitate to give Ricardo full credit for his arguments related to comparative advantages obtained by free international trade; but Keynes added, are these arguments relevant today? He was referring to Ricardo's stylized model and even more importantly to the loss of sovereignty with regard to undertaking national macroeconomic policies to stabilize employment (and production). Keynes would not deny that - with the theoretical models - there could be some long run gains to be obtained from international trade (but not until the 'tempestuous season is over'); but the short term losses might be significant - and even worse, the long run gains might never appear. These perspectives brought the more mature (and disillusioned) Keynes to the conclusion that international economics had to be regulated, because there would be no benefit from a nonregulated market system and a neutralized political system, either nationally or domestically.

Hence, after the Second World War and the implementation of the Bretton Woods System (an intellectual and political construction with inspiration from Keynes), serious economists should 
have known the theoretical arguments explaining macroeconomic imbalances. During the 1950s and 1960s, they got the empirical 'proof of the pudding': high growth rates and full employment within an international system characterized by fixed but adjustable exchange rates and financial capital control. ${ }^{\mathrm{i}}$

Even Robert Mundell, a Canadian economist with monetarist inclination writing in the 1960s (Nobel Prize winner in 1999) about the conditions related to identifying an 'Optimal Currency Area', had to admit that giving up the national currency would in most cases create a number of macroeconomic difficulties, which reduced transaction costs could not compensate for. He pointed at the lack of factor (labour and real capital) mobility as an essential factor in deciding on not giving up a national currency ${ }^{\mathrm{ii}}$. Many Keynesian economists would have added that giving up a national currency also implies a severe amputation of demand management policies.

\section{Parguez's accusation: How could economists by so wrong on the common currency?}

Against this theoretical background, Parguez asks the question: how can it be that serious macroeconomists, who have the above mentioned knowledge, could - and still can - claim that the European Union gains economically and politically from having a common currency? In the interwar period the Walrasian general equilibrium model was - until Keynes - the only macroeconomic framework, and it gave unconditional support to the national gold standard. But history in the 1930s and further on in the 1950s and 1960s had demonstrated that unchangeable exchange rates might cause economic catastrophe. ${ }^{\text {iii }}$

I can understand politicians who have a dream and a vision of a unified Europe supporting intuitively the common European currency. For instance, Charles DeGaulle objected in the 1960s to Britain being a member of the EEC because he considered that it would reduce French dominance. But in reality France could not prevent the German economy from prospering and the German Dmark becoming the key currency within Europe. The Dmark became the anchor of the European 
Monetary System established in 1979. France (and the other participating countries) had to adjust their rate of interest to the decisions of the Bundesbank, which of course was a thorn in the side of French governments. But Parguez is right when he accuses the French economic profession (elite) of being cynical in envisaging that a unification of Europe could be established under an umbrella of French 'glory', because they knew better from theory and history.

In any event, the French elite supported the idea that the dominance of the Dmark could be clipped by the introduction of a common currency and a European Central Bank. The board of governors should consist of only one representative from each participating country - like the EU Commission - and only be given one vote each, when the European rate of interest was decided on. This way of decision making would scale down German might, it was argued by the French government. To give intellectual and economic support to this idea of one currency and a more balanced European monetary policy, the Delors Commission was set up in 1988 by the European Council. The Commission was headed by Jacques Delors and consisted of the twelve (EU member states') central bank governors plus three 'external' economic experts ${ }^{\text {iv }}$. When re-reading the Delors report (Committee on the Study of Economic and Monetary Union (1989)), it seems astonishing that not a single caveat indicating the possible failures of the common currency was put forward in the main text. Even in the supporting notes by the individual members of the Commission, you find hardly any reservation regarding the idea of a monetary union; and even more surprisingly, you find no serious objection to the conclusion that the majority of EU countries could within less than ten years represent an 'optimal currency area'. Hence, the idea of monetary/fiscal transfers from 'winners' to 'losers' was not even mentioned, because it was concluded that all participants would gain due to lower transaction costs and enlarged foreign trade. Only the German central bank governor, Karl Otto Pöhl, had sceptical comments: first, he wondered how many countries really were ready to adopt a common currency, and secondly, he doubted that the monetary union could work well without being supported by an (emerging) political union. But no one paid really attention to these reservations when monetary union was negotiated as a part of the Maastricht 
Treaty, partly because Karl Otto Pöhl shortly afterwards had been on a collision course with Chancellor Helmut Kohl regarding the monetary unification between East and West Germany at one-to-one parity. Anyway, Delors was very eager to prevent any dissenting viewpoints, which gave the monetarist view of the central bankers the upper hand. Hence, the euro-monetarist, i.e. the German view, on how to organize the monetary union, not the French one, got the final word when the report and later the Maastricht treaty was written: the ECB being independent of the political system and with its sole focus as combating price inflation. ${ }^{\mathrm{v}}$

The European Commission (with Jacques Delors as chairman, 1986-96) was of course very active in its propaganda for the monetary union. The Commission published a number of uncritical reports. The one most often quoted is 'One Market, One Money' (1990). The common currency would indisputably facilitate the integration of the national markets within the EU due to lowering transaction costs and thereby supporting the 'single markets' in goods, services and financial capital. In addition, it was recommended that the money supply would come under the control of economic technocrats, because the ECB board was explicitly given the task of conducting monetary policy without any instructions from the political system, which would bring future inflation firmly under control

When the crisis hit in 2008, it was demonstrated that the French elite and the German view (the ECB's) were both entirely wrong, for at least four reasons:

1. The euro-countries did not converge after they joined the euro-zone. But the Brussels Elite and the ECB did not pay attention to real sector imbalances; they were only watching the average rate of consumer price inflation and the public sector deficit. They did not care about deviations in the cost level of member states and the following relative changes in international competitiveness, which made huge balance of payments imbalances build up in creditor countries (Germany, The Netherlands etc.) and similar huge deficits in high cost, high growth (1999-2007) Southern Europe - see figure 1. 


\section{Figure 1: Balance of Payments position by Country 1999, 2008 and 2011}

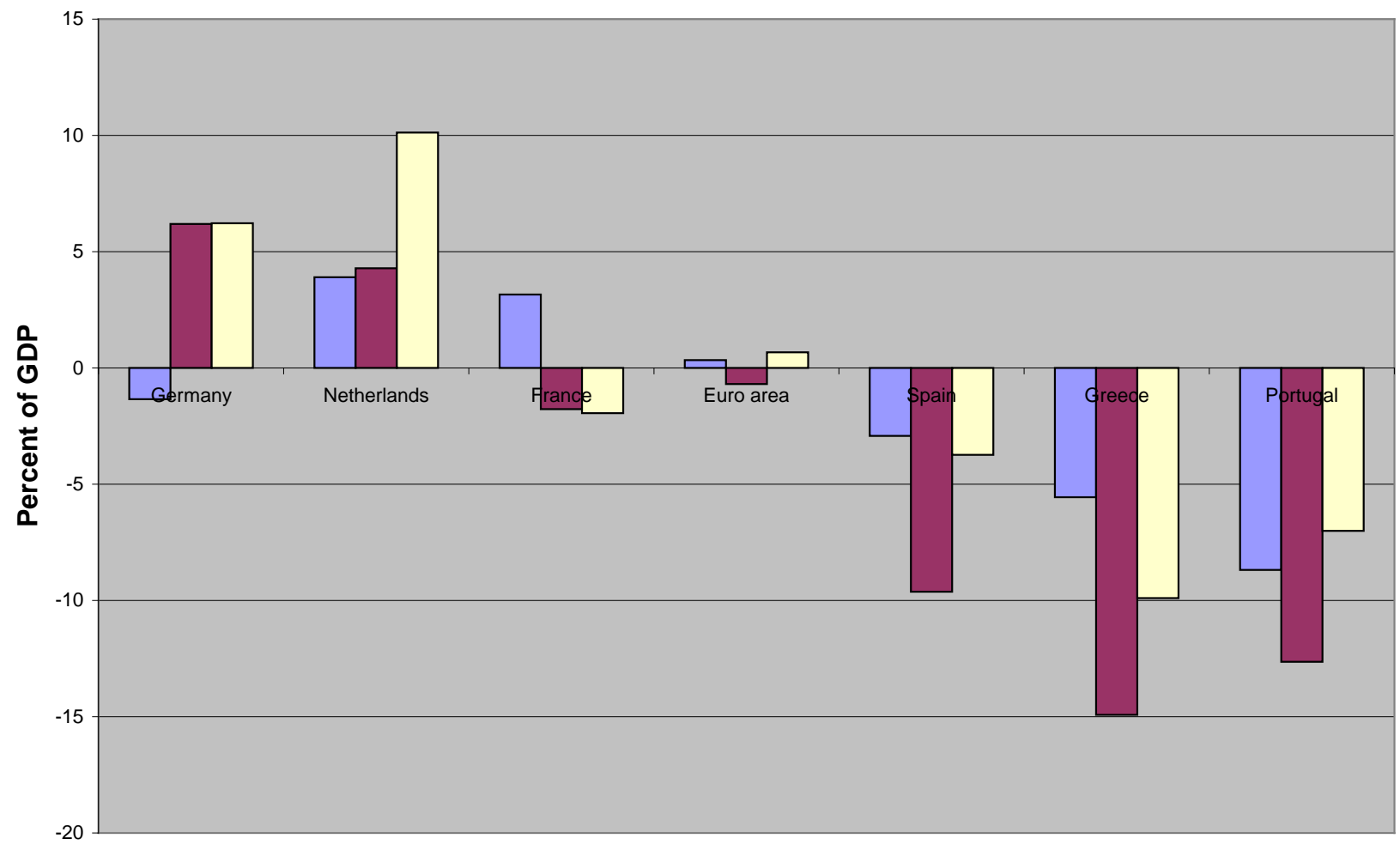

Source: OECD, Economic Outlook, November 2015

Notes: 1. The euro-zone(15) as a whole was approximately in balance during this period.

2. German surplus of 7 pct. of GDP adds up to more than 100 bill. euro

2. The euro-monetarists argued that the common currency had removed the balance of payments constraint from the participating countries. They were entirely wrong. Countries with the largest foreign debt and current account deficits were those who were hardest hit when the financial crisis struck. Within a few weeks, foreign credit lines were cut off. Private banks in deficit countries were immediately liquidity-squeezed due to their short term borrowing on the interbank market. In this situation, two things could have happened: either the German, French and Dutch private banks would experience a lot of distressed lending to Southern European banks because of private sector bankruptcies, or Southern European governments would have to step in and bail out private banks. Governments in Southern Europe (and Ireland) did step in (more or less under pressure from Brussels!), The consequences for public finances in these countries were devastating, because public sector debt grow unprecedentedly, leading to the so-called sovereignty debt crisis. This arm- 
twisting between the Northern countries and Brussels (representing creditor banks) on one side and Southern countries (representing debtor banks) on the other took place in 2010, where of course the weak debtor nations lost. This scenario has been repeated twice in the case of Greece - each time with the debtor country being humiliated. The Troika representing the creditor countries asked devastating conditions in return for just providing the debtor countries with enough liquidity to repay previous borrowing and re-capitalize private banks. In the end, this so-called financial support was mainly organized as rescue packages to help the Northern banks to get rid of their distressed lending to the South.

3. The money supply had run out of control. It is a false idea that any central bank can control the money supply. Private banks have the upper hand, because it is the amount of bank lending, buying bonds etc. which determines the amount of bank deposits. In any event, in the present situation, the excess supply of money had hardly any impact on the consumer price level, which, in fact, came as a surprise to the ECB economists. On the other hand, they should not have been surprised by the impact on asset prices and the inherent risks related to asset price bubbles. But the ECB governors acted as though they did not see any inflation; hence there was no reason to limit bank credit. They were wrong - as we now know and they should have known!

4. Finally, as Parguez rightly stresses (p. 17), the euro-monetarists mistake the real economy for a 'Walrasian Equilibrium state'. To them, private and public sector expenditures compete on scarce factors of production. But here also they are wrong. Unemployment has for 40 years been far above any reasonably defined structural level, which can be seen from the statistics. Today more than 25 million people are unemployed in Europe (before adding the refugees). One consequence has been falling nominal wage inflation, falling wage share and structural excess financial savings in the private sector. In this case, public sector real investments are indispensable to make the private sector re-start and recover. But instead, austerity policies reduce private real investment even 
further and hence, increase the structural imbalances of the private sector (and labour market).

\section{Conclusion: Debunked economics ${ }^{\text {vi }}$}

Finally, the French elite have to realize that their strategy of being 'primus inter pares' in an integrating Europe failed in the inter-war period and once again in setting up the common European currency. But this time there is no excuse, because the economists knew better. It should have come as no surprise that the common currency in stead has supported the German revival. Germany's superiority in industrial productivity and suppressing inflation is second to none, which has caused huge balance of payments and unemployment imbalances to build up within the euro-zone.

In many ways one could summarize Parguez's paper by posing a concluding question: is the economic Elite, not only in France, but in the dominant European institutions in general, incompetent, ideologically biased or just a 'rent seeking' profession? He is particularly right to ask this question given that the Elite already knew the relevant theories and had experiences, which told them that the dynamics of modern capitalism is not supporting the idea of a self-correcting market system. ${ }^{\text {vii }}$ How can it then be that they contrary to the available knowledge cling to the out-dated general equilibrium theory? And even worse - for the European people - they did not change their minds when reality once again demonstrates that Europe suffers from a persistent crisis and their suggested policies do not deliver the proclaimed outcome?

These failed economic policy advices have brought so much social hardship to Europe that the trust in the original idea of European collaboration being to the benefit of ordinary people has been challenged. The growing dissatisfaction is gaining strong support in the hands of populist politicians, which could lead to an ever larger catastrophe.

\section{Literature}

Amoroso, B. and J. Jespersen. 2012. L'Europa oltre l'Europa. Rome: RX-CastelVecchi.

Committee on the Study of Economic and Monetary Union. 1989. Report on Economic and Monetary Union in the European Community. Luxembourg: Office for Official Publications of the European Communities. 
Commission of the European Communities. 1990. “One Market, One Money.” European Economy 44.

Davidson, P. 2009. The Keynes Solution. Cheltenham: Edward Elgar.

De Grauwe, P. 2012. Economics of Monetary Union, $9^{\text {th }}$ ed. Oxford: Oxford University Press.

Eyrand L. and A. Weber. 2013. The Challenge of Debt Reduction during Fiscal Consolidation, IMF Working Paper, 13/67.

Hoffmeyer, E. 2000. Decision making for European Economic and Monetary Union. Occasional Paper 62. published by the Group of Thirty.

Issing, O. et al. 2001. Monetary Policy in the Euro Area, Strategy and Decision Making at the European Central Bank. Cambridge: Cambridge University Press.

Jespersen, J. 2002. "Why so much macroeconomic disagreement on the EMU?" In Money, Macroeconomics and Keynes. Festschrift to Victoria Chick, edited by Ph. Arestis, S. Dow \& M. Dessai. London: Routledge.

Jespersen, J. 2004. “The Stability Pact: a Monetary Straitjacket.” in The Price of the Euro edited by J. Ljungberg. Basingstoke: Palgrave.

Jespersen, J. 2005. “Exchange Rate Arrangements and EU Enlargement.” in L.- Ph. Rochon and S. Rossi (eds). Monetary and Exchange Rate Systems - a Global View of Financial Crises.

Cheltenham: Edward Elgar.

Jespersen, J. 2014. “The Economic Consequences of the Euro: Lessons from History”. Chapter 7 in J. Hölscher and M. Klaes (eds), Keynes's economic consequences of the Peace: a Reappraisal. London: Pickering \& Chatto.

Keynes, J. M. 1919. The Economic Consequences of the Peace, in E. Johnson and D. Moggridge (eds). 1973. The Collected Writings of John Maynard Keynes, vol. II. London: Macmillan and Cambridge University Press.

Keynes, J. M. 1933. ”National Self-Sufficiency.” The Yale Review, Vol. 22, no. 4: 755-769.

Keynes, J. M. 1936. The General Theory of Employment, Interest and Money, in E. Johnson and D. Moggridge (eds). 1973. The Collected Writings of John Maynard Keynes, vol. VII. London: Macmillan and Cambridge University Press.

Mundell, R. 1961. “A Theory of Optimal Currency Areas.” American Economic Review, 51 (4): 657-665.

Mundell, R. 1973. “Uncommon Arguments for Common Currencies”, in H. Johnson and A. Swoboda. The Economics of Common Currencies. London: Allan \& Unwin.

Sørensen, P. B. (ed.). 2005. Monetary Union in Europe: Historical Perspectives and Prospects for the Future: Essay in Honour of Niels Thygesen. Copenhagen: DJØF Publishing. 
${ }^{\mathrm{i}}$ This theoretical development in real world macroeconomics is beautifully told in Davidson. 2009. ${ }^{i i}$ But later, after being consultant to the Monetary Committee of the European Economic Commission, and in 1972-3 a member of the nine consultants to the Commission that prepared a report in Brussels on European monetary integration, he played a significant role in the founding of the euro, according to his official CV, http://www.columbia.edu/ ram15/bob2000.html, see also Mundell. 1973 and Sørensen (ed.). 2005.

iii In the preface to the French edition of 'The Economic Consequences of the Peace' , Keynes made 'an appeal beyond the French politicians [and economists] to the intelligence of France, to that element in the French mind which delights to see things as they are and to draw the consequences'. (Keynes, 1919: xxii), for a deeper discussion of the consequences of the French aspiration after the first world war, see for instance, Jespersen. 2014.

iv'External' is in quotation marks, because all three economists were known as being in favour of the idea of setting up a monetary union in Europe.

${ }^{v}$ The Danish Central Bank governor got later in his carrier second thought on the advantages of setting up a monetary union in the present form at the present time, see Hoffmeyer. 2000

vi Together with my Italian colleague Dr. Bruno Amoroso and I have discussed the increasing fragility of the European Monetary Union in a North-South perspective, as different from the French perspective.

vii As Parguez correctly points out, this is no a new situation. He has contribution from the very start of the Monetary Union emphasized the theoretically hollowness, that the arguments in favour of the EMU were better explained by ideology than realistic macroeconomic theory, which I have propagated in the Scandinavian countries see for instance, Jespersen. 2002, 2004 and 2005. Empirical support was ample, but at last canonized by IMF, se for instance, Eyrand and Weber. 2013. It is also telling how one of the most read textbooks on the Monetary Union by Paul De Grauwe is lacking behind reality. Not until the 11th edition expected in April 2016 has the word euro-exit not to speak of a theoretical discussion been mentioned. The possibility of a financial crisis in the euro-zone had to wait until the $9^{\text {th }}$ edition (2012) and was devoted just a couple of pages. 